\title{
sciendo
}

\section{REDOX AND IMMUNOLOGICAL STATUS OF TURKEYS FED DIETS WITH DIFFERENT LEVELS AND SOURCES OF COPPER*}

\author{
Jan Jankowski ${ }^{1}$, Krzysztof Kozłowski ${ }^{1}$, Katarzyna Ognik ${ }^{2}$, Zenon Zduńczyk ${ }^{3}$, Kamil Otowski ${ }^{1}$, \\ Ewa Sawosz ${ }^{4}$, Jerzy Juśkiewicz ${ }^{3 \bullet}$
}
${ }^{1}$ Department of Poultry Science, Faculty of Animal Bioengineering, University of Warmia and Mazury in Olsztyn, Oczapowskiego 5, 10-719 Olsztyn, Poland
${ }^{2}$ Department of Biochemistry and Toxicology, Faculty of Biology, Animal Sciences and Bioeconomy, University of Life Sciences in Lublin, Akademicka 13, 20-950 Lublin, Poland
${ }^{3}$ Institute of Animal Reproduction and Food Research of the Polish Academy of Sciences,
Tuwima 10, 10-748 Olsztyn, Poland
${ }^{4}$ Faculty of Animal Science, Department of Animal Nutrition and Biotechnology, Warsaw University of Life Sciences, Ciszewskiego 8, 02-786 Warszawa, Poland
•Corresponding author: j.juskiewicz@pan.olsztyn.pl

\begin{abstract}
This study, performed on turkeys aged 1 to 98 days, aimed to investigate whether different dietary inclusion levels $\left(20,10,2 \mathrm{mg} \mathrm{kg} \mathbf{~ k}^{-1}\right)$ of copper nanoparticles (Cu-NP) as a substitute for copper sulphate (Cu-SUL) affect redox and immunological status of turkeys' tissues. No significant differences in the final body weights of turkeys were found across the dietary treatments. A comparison of the physiological effects of $\mathrm{Cu}-\mathrm{NP}$ and $\mathrm{Cu}-\mathrm{SUL}$ revealed equivocal metabolic responses including decreased superoxide dismutase (SOD) activity in the liver, increased SOD and catalase activities in breast muscles, decreased total glutathione concentrations in breast muscles, and decreased plasma IgY concentrations. An analysis of the antioxidant and immune status parameters in the blood, liver and breast meat of turkeys indicates that $10 \mathrm{mg} / \mathrm{kg}$ is the optimal inclusion level of additional $\mathrm{Cu}$. Both two-fold higher and five-fold lower $\mathrm{Cu}$ supplementation levels have a negative influence on selected parameters of the antioxidant and immune status of birds. Lower supplementation levels of $\mathrm{Cu}-\mathrm{NP}(2$ and $10 \mathrm{mg} / \mathrm{kg})$ exert similar physiological effects to $\mathrm{Cu}-\mathrm{SUL}$, whereas higher addition of $\mathrm{Cu}-\mathrm{NP}(20 \mathrm{mg} / \mathrm{kg})$ may negatively affect selected redox parameters and stimulate the synthesis of the proinflammatory cytokine IL-6. The results of the present study indicate that further research is needed to establish the actual dietary requirements for $\mathrm{Cu}$ in turkeys and the efficacy of nanoparticles as a new additional $\mathrm{Cu}$ source in turkey nutrition.
\end{abstract}

Key words: turkey, nano-copper, redox status, immunity, breast meat

Copper $(\mathrm{Cu})$ participates in most of enzymatic reactions and cellular metabolism. In addition, $\mathrm{Cu}$ is essential for a wide range of health and performance-related

*This work was supported by the National Centre for Research and Development: [Biostrateg program "GUTFEED - innovative nutrition in sustainable poultry production"; No. 267659/7/NCBR/2015], Poland. 
functions in all animal species (Klasing, 1998). An adequate amount of dietary $\mathrm{Cu}$ is required for the proper functioning of the circulatory system in animals (Kim et al., 1992), which is an important consideration in view of the sudden death syndrome and other cardiovascular diseases in fast-growing birds. Therefore, $\mathrm{Cu}$ is one of the ingredients of typical mineral premixes routinely used in poultry nutrition, and the recommended amount of supplemental $\mathrm{Cu}$ has been increased from $8 \mathrm{mg} \mathrm{kg}^{-1}$ to $20 \mathrm{mg} \mathrm{kg}^{-1}$ (NRC, 1994; Hybrid Turkeys, 2013, respectively). However, the amount of $\mathrm{Cu}$ used in the poultry diets can reach up to $25 \mathrm{mg} \mathrm{kg}^{-1}$. The European Food Safety Authority (EFSA) published the newly proposed maximum content of $\mathrm{Cu}$ in complete diets for targeted animals to reduce the amount of $\mathrm{Cu}$ released into the environment (EFSA, 2016). This is an important consideration since a large proportion of inorganic $\mathrm{Cu}$ salts such as sulphate remains in poultry excreta and contaminates the environment (Maheshwari, 2013). On the other hand, organic forms of $\mathrm{Cu}$, which are better utilised by poultry (Nollet et al., 2008; Mikulski et al., 2009), are not in wide use.

Recent research has shown that nano-minerals, including $\mathrm{Cu}$ nanoparticles, could be used as feed additive to improve growth rate, digestion and absorption in poultry and livestocks (Bunglavan et al., 2014; Ognik et al., 2016; Hill and Li, 2017; El Sabry et al., 2018). Due to the special characteristics of nanoparticles such as shape, small size, large surface area, which enhance activity of this form of minerals, some new properties of nanoparticles could be expected (Albanese et al., 2012; Majewski et al., 2017; Tomaszewska et al., 2017; El Sabry et al., 2018). This may be a key feature of $\mathrm{Cu}$ nanoparticles in view of the need to reduce the amount of $\mathrm{Cu}$ in animal diets and to minimize the amount of $\mathrm{Cu}$ released into the environment. From the consumer's point of view, a reduction in $\mathrm{Cu}$ accumulation in edible carcass parts as well as the health benefits and high quality of meat are of utmost importance. Therefore, the aim of this study was to investigate whether the dietary inclusion of $\mathrm{Cu}-\mathrm{NP}$ as a substitute for $\mathrm{Cu}$-SUL affects the growth performance, redox and immune status of turkeys.

\section{Material and methods}

\section{Birds and dietary treatments}

The experiment was approved by the local Ethics Committee for Experiments on Animals in Olsztyn (permission No. 30/2015; 2015.04.29). A total of 648 one-dayold Hybrid Converter female turkey poults were placed in 36 pens, and were raised in accordance with the recommendations of a breeder management guide. Turkey poults were divided into 6 groups with 6 replicates per group (each of 18 poults), in a two-factorial design with 3 dietary inclusion levels of $\mathrm{Cu}(20,10$ and $2 \mathrm{mg} / \mathrm{kg})$ and 2 dietary forms that contained either $\mathrm{Cu}$ - conventional copper sulphate $(\mathrm{Cu}-\mathrm{SUL})$ or $\mathrm{Cu}$ nanoparticles (Cu-NP) (25 $\mathrm{nm}$ in size) in the form of $99.8 \%$ purity powder (purchased from the Sky Spring Nanomaterials Inc., Houston, TX), which were added to a vitamin-mineral premix using a carbohydrate carrier. All birds had free access to water and feed prepared in the local "Agrocentrum" Feed Mill Ltd. The composition of pelleted and crumbled experimental diets is shown in Table 1. 
Table 1. Composition and the calculated nutritional value of experimental turkey basal diets ( $\mathrm{g} \mathrm{kg}^{-1}$ as-fed basis)

\begin{tabular}{|c|c|c|c|}
\hline \multirow{2}{*}{ Item } & \multicolumn{3}{|c|}{ Experimental period (days of age) } \\
\hline & $1-42$ & $43-70$ & $71-98$ \\
\hline \multicolumn{4}{|l|}{ Ingredients $\left(\mathrm{g} \mathrm{kg}^{-1}\right)$} \\
\hline wheat & 431.1 & 462.0 & 616.6 \\
\hline soybean & 389.7 & 304.6 & 159.5 \\
\hline faba bean & 100.0 & 100.0 & 100.0 \\
\hline rapeseed & - & 50.0 & 60.0 \\
\hline soybean oil & 28.0 & 38.6 & 35.4 \\
\hline sodium sulphate & 1.5 & 1.5 & 1.5 \\
\hline salt & 2.0 & 1.6 & 1.7 \\
\hline limestone & 16.0 & 15.7 & 8.5 \\
\hline monocalcium phosphate & 17.5 & 13.2 & 6.7 \\
\hline methionine & 3.7 & 2.6 & 2.0 \\
\hline lysine & 4.4 & 4.0 & 3.7 \\
\hline threonine & 1.2 & 1.2 & 0.5 \\
\hline vitamin-mineral premix* & 5.0 & 5.0 & 4.0 \\
\hline \multicolumn{4}{|l|}{ Nutritional value ${ }^{* *}$} \\
\hline $\operatorname{AME}\left(\mathrm{kcal} \mathrm{kg}^{-1}\right)$ & 2750 & 2950 & 3100 \\
\hline protein & 265.0 & 230.0 & 185.0 \\
\hline fibre & 34.0 & 39.8 & 35.7 \\
\hline fat & 42.3 & 71.6 & 73.7 \\
\hline arginine & 17.6 & 15.2 & 11.8 \\
\hline lysine & 17.4 & 15.0 & 11.7 \\
\hline methionine & 7.1 & 5.7 & 4.5 \\
\hline methionine and cysteine & 11.3 & 9.5 & 7.8 \\
\hline threonine & 10.5 & 9.3 & 6.8 \\
\hline tryptophan & 3.2 & 2.9 & 2.2 \\
\hline calcium & 11.5 & 10.5 & 6.5 \\
\hline non-phytin phosphorus & 5.5 & 4.5 & 3.0 \\
\hline natrium & 1.5 & 1.3 & 1.3 \\
\hline
\end{tabular}

*Per kg of diet: vitamin A - 24999.75 IU, vitamin D - $35000 \mathrm{IU}$, vitamin E - $100 \mathrm{IU}$, tocopherol - $91 \mathrm{mg}$, vitamin $\mathrm{K}-4 \mathrm{mg}$, vitamin $\mathrm{B}_{1}-5 \mathrm{mg}$, vitamin $\mathrm{B}_{2}-15 \mathrm{mg}$, vitamin $\mathrm{B}_{6}-6 \mathrm{mg}$, vitamin $\mathrm{B}_{12}-0.04 \mathrm{mg}$, niacin -100 $\mathrm{mg}$, pantothenic acid - $30 \mathrm{mg}$, folic acid $-4 \mathrm{mg}$, choline chloride $-700 \mathrm{mg}$, calcium d-pantothenate -32.665 $\mathrm{mg}$, biotin $-0.35 \mathrm{mg}$, total $\mathrm{Se}-0.3 \mathrm{mg}$, total $\mathrm{Fe}-60 \mathrm{mg}$, total $\mathrm{Mn}-100 \mathrm{mg}$, total $\mathrm{Zn}-100 \mathrm{mg}, \mathrm{J}-1.5 \mathrm{mg}$, $\mathrm{Ca}-1.0435 \mathrm{~g}$

** The content of nutrients and non-nutrients was calculated according to the Polish Feedstuff Analysis Tables (Smulikowska and Rutkowski, 2005).

The turkey poults were weighed at the beginning of the experiment and then after 6, 10 and 14 weeks of experimental feeding. In none of the periods were there any differences between the experimental treatments. At the termination of the study, one bird was selected from each pen for the collection of physiological tests. The body 
weight of the selected turkeys, 6 per each nutritional treatment, was in the range of $+/-10 \%$ of the experimental mean, $9.51 \mathrm{~kg}$.

\section{Sampling and analyses}

Blood samples $(5 \mathrm{ml})$ were collected from the wing vein into test tubes with an anticoagulant (heparin), which were centrifuged at $380 \mathrm{~g}$ for $10 \mathrm{~min}$ at $4^{\circ} \mathrm{C}$, and plasma was collected for further analysis. The levels of haemoglobin $(\mathrm{Hb})$ and haematocrit (Ht) in blood were measured using an automatic haematology analyser (Abacuss Junior Vet, Diatron, Hungary). In erythrocytes, superoxide dismutase (SOD) activity was measured using the Ransod kit (Randox), glutathione peroxidase (GPx) activity was measured by the Ransel kit (Randox). Catalase (CAT) activity, the level of total antioxidant potential (FRAP), concentrations of total glutathione (GSH + GSSG) and malondialdehyde (MDA) in blood plasma, as well as redox parameters in liver and breast muscle samples were measured as previously described (Ognik and Wertelecki, 2012). The immune system response of turkey poults was determined based on immunoglobulins (IgA, IgM, IgY) level in the plasma (using the ELISA kits from Elabscience Biotechnology Co., Ltd.), interleukin 6 (IL-6, using USCN Life Science Inc. kits), ceruloplasmin (Cp) and lysozyme. Blood plasma lysozyme activity was determined with the sandwich ELISA kit, and ceruloplasmin (Cp) was determined by the $p$-phenylenediamine colorimetric method according to Sunderman and Nomoto (1970). The $\mathrm{Cu}$ content of samples of diets and tissues was determined by inductively coupled plasma optical emission spectrometry (ICP-OES).

\section{Statistical analysis}

Two-way ANOVA was performed to determine the effects of different inclusion levels $(20,10$ and $2 \mathrm{mg} / \mathrm{kg}$ ) and forms of additional $\mathrm{Cu}(\mathrm{Cu}-\mathrm{SUL}$ or $\mathrm{Cu}-\mathrm{NP})$, and the interaction between both factors (addition $\times$ form; $A \times F$ ). In the case of a significant $\mathrm{A} \times \mathrm{F}$ interaction, the significance of differences between mean values of the analysed parameters in groups was estimated by Duncan's multiple range test. Data were checked for normality before statistical analyses were performed. Treatment effects were considered to be significant at $\mathrm{P}<0.05$. The results were processed in the STATISTICA PL 12.0 application.

\section{Results}

The $\mathrm{Cu}$ content of all experimental diets was close to the value assumed in the experimental design and slightly decreased as the birds grew older (Table 2). The minor differences observed between groups could have resulted from different $\mathrm{Cu}$ concentrations in feed ingredients used for formulating diets in successive stages of the feeding trial. The difference between the total $\mathrm{Cu}$ content of diets and supplemental $\mathrm{Cu}$ doses indicates that major feed ingredients provided approximately $11 \mathrm{mg} \mathrm{kg}^{-1} \mathrm{Cu}$ in total. 
Table 2. The total content of $\mathrm{Cu}$ in turkey experimental diets $\left(\mathrm{mg} \mathrm{kg}^{-1}\right)$

\begin{tabular}{l|c|c|c}
\hline \multirow{2}{*}{ Experimental diets* } & \multicolumn{3}{c}{ Experimental period (days) } \\
\cline { 2 - 4 } & $1-42$ & $43-70$ & $71-102$ \\
\hline $\mathrm{Cu}^{*} \mathrm{SUL}_{20}$ & 31.2 & 29.1 & 30.7 \\
$\mathrm{Cu}_{20} \mathrm{NP}_{20}$ & 28.4 & 27.2 & 26.9 \\
$\mathrm{Cu}_{\mathrm{SUL}}$ & 21.1 & 17.9 & 18.8 \\
$\mathrm{Cu}-\mathrm{NP}_{10}$ & 20.4 & 18.3 & 17.6 \\
$\mathrm{Cu}-\mathrm{SUL}_{2}$ & 14.9 & 12.6 & 12.9 \\
$\mathrm{Cu}-\mathrm{NP}_{2}$ & 13.7 & 13.4 & 12.5 \\
\hline
\end{tabular}

*Diet supplemented with 20,10 and $2 \mathrm{mg}$ of additional $\mathrm{Cu}$ in the form of sulphate $\left(\mathrm{Cu}-\mathrm{SUL}_{20}, \mathrm{Cu}-\mathrm{SUL}_{10}\right.$, $\left.\mathrm{Cu}-\mathrm{SUL}_{2}\right)$ or nanoparticles $\left(\mathrm{Cu}-\mathrm{NP}_{20}, \mathrm{Cu}-\mathrm{NP}_{10}, \mathrm{Cu}-\mathrm{NP}_{2}\right)$. The total $\mathrm{Cu}$ content originated from the basal diets and supplemental copper.

Table 3. Cu level and redox status parameters of blood/plasma of birds*

\begin{tabular}{|c|c|c|c|c|c|c|c|}
\hline & $\begin{array}{c}\mathrm{Cu} \\
\left(\mathrm{umol} \mathrm{L}^{-1} \text { ) }\right.\end{array}$ & $\begin{array}{l}\text { SOD } \\
\left(\mathrm{U} \mathrm{g}^{-1}\right)\end{array}$ & $\begin{array}{l}\text { CAT } \\
\left(\mathrm{U} \mathrm{g}^{-1}\right)\end{array}$ & $\begin{array}{c}\text { GPx } \\
\left(\mathrm{U} \mathrm{g}^{-1}\right)\end{array}$ & $\begin{array}{c}\mathrm{GSH}+\mathrm{GSSG} \\
\left(\mu \mathrm{mol} \mathrm{L}{ }^{-1}\right)\end{array}$ & $\begin{array}{c}\text { FRAP } \\
(\mu \mathrm{mol} \mathrm{L}-1)\end{array}$ & $\begin{array}{c}\text { MDA } \\
(\mu \mathrm{mol} \mathrm{L}-1)\end{array}$ \\
\hline \multicolumn{8}{|l|}{ Group } \\
\hline $\mathrm{Cu}-\mathrm{SUL}_{20}$ & $2.81 \mathrm{~b}$ & 1784 & $574 \mathrm{a}$ & $56.0 \mathrm{c}$ & 0.114 & 499 a & 0.56 \\
\hline $\mathrm{Cu}-\mathrm{NP}_{20}$ & $4.62 \mathrm{a}$ & 1516 & $339 \mathrm{~b}$ & $50.1 \mathrm{c}$ & 0.120 & $551 \mathrm{a}$ & 0.79 \\
\hline $\mathrm{Cu}-\mathrm{SUL}_{10}$ & $3.93 \mathrm{ab}$ & 1097 & $399 \mathrm{~b}$ & $51.2 \mathrm{c}$ & 0.107 & $568 \mathrm{a}$ & 0.65 \\
\hline $\mathrm{Cu}-\mathrm{NP}_{10}$ & $3.96 \mathrm{ab}$ & 1666 & $381 \mathrm{~b}$ & $54.5 \mathrm{c}$ & 0.102 & $506 \mathrm{a}$ & 0.70 \\
\hline $\mathrm{Cu}-\mathrm{SUL}_{2}$ & $3.70 \mathrm{ab}$ & 2337 & $220 \mathrm{c}$ & $70.4 \mathrm{~b}$ & 0.161 & $420 \mathrm{~b}$ & 0.95 \\
\hline $\mathrm{Cu}-\mathrm{NP}_{2}$ & $3.36 \mathrm{ab}$ & 2082 & $237 \mathrm{c}$ & $79.3 \mathrm{a}$ & 0.112 & $339 c$ & 0.94 \\
\hline SEM & 0.179 & 105.4 & 20.502 & 4.344 & 0.008 & 14.75 & 0.032 \\
\hline \multicolumn{8}{|l|}{$\mathrm{Cu}$ addition (A) } \\
\hline $20 \mathrm{mg} \mathrm{kg}^{-1}$ & 3.72 & $1650 \mathrm{~b}$ & 456 & 53.0 & 0.117 & 525 & $0.68 \mathrm{~b}$ \\
\hline $10 \mathrm{mg} \mathrm{kg}^{-1}$ & 3.94 & $1382 \mathrm{~b}$ & 390 & 52.8 & 0.105 & 537 & $0.67 \mathrm{~b}$ \\
\hline $2 \mathrm{mg} \mathrm{kg}^{-1}$ & 3.53 & $2209 \mathrm{a}$ & 229 & 74.9 & 0.136 & 379 & $0.94 \mathrm{a}$ \\
\hline $\mathrm{P}$ values & 0.610 & 0.003 & 0.001 & 0.009 & 0.227 & 0.001 & 0.001 \\
\hline \multicolumn{8}{|l|}{$\mathrm{Cu}$ form $(\mathrm{F})$} \\
\hline Cu-SUL & 3.48 & 1739 & 398 & 59.2 & 0.127 & 496 & 0.72 \\
\hline $\mathrm{Cu}-\mathrm{NP}$ & 3.98 & 1755 & 319 & 61.3 & 0.111 & 465 & 0.81 \\
\hline P values & 0.147 & 0.933 & 0.002 & 0.040 & 0.285 & 0.126 & 0.110 \\
\hline $\mathrm{A} \times \mathrm{F}$ interaction & 0.028 & 0.123 & 0.001 & 0.001 & 0.287 & 0.015 & 0.164 \\
\hline
\end{tabular}

*SOD, superoxide dismutase; CAT, catalase; GPx, glutathione peroxidase; GSH+GSSG, total glutathione; FRAP, ferric reducing ability of plasma; MDA, malondialdehyde

$\mathrm{a}, \mathrm{b}, \mathrm{c}-$ mean values within a column with unlike letters were shown to be significantly different $(\mathrm{P}<0.05)$; differences among the groups $\mathrm{Cu}-\mathrm{SUL}_{20}, \mathrm{Cu}-\mathrm{SUL}_{10}, \mathrm{Cu}-\mathrm{SUL}_{220}, \mathrm{Cu}-\mathrm{NP}_{20}, \mathrm{Cu}-\mathrm{NP}_{10}$, and $\mathrm{Cu}-\mathrm{NP}_{2}$ were indicated with superscripts only in the case of a statistically significant interaction $\mathrm{A} \times \mathrm{F}(\mathrm{P}<0.05)$.

After 14 weeks of feeding the average body weight of turkeys from individual treatments was within a narrow range of 9.43-9.56 kg ( $P>0.05$; data not shown in tables). For diets supplemented with various amounts and forms of $\mathrm{Cu}$, none of the experimental factors affected the body weights. A level $\times$ form interaction was observed for plasma $\mathrm{Cu}$ concentrations, which were comparable in all four groups 
treated with 10 and $2 \mathrm{mg} \mathrm{kg}^{-1}$ of additional $\mathrm{Cu}$ whereas the highest and the lowest $\mathrm{Cu}$ plasma concentrations were noted in groups $\mathrm{Cu}-\mathrm{NP}_{20}$ and $\mathrm{Cu}-\mathrm{SUL}_{20}$, respectively $(\mathrm{P}<0.05)$ (Table 3). An interaction was noted for blood CAT and GPx activity which was highest in the $\mathrm{Cu}-\mathrm{SUL}_{20}$ treatment. The lowest blood CAT activity was observed in turkeys fed diets supplemented with $\mathrm{Cu}$ at $2 \mathrm{mg} \mathrm{kg}^{-1}$, irrespective of $\mathrm{Cu}$ form $(\mathrm{P}<0.05$ vs. all other groups). A level $\times$ form interaction was also noted for GPx blood activity: a dietary $\mathrm{Cu}$ dose of $2 \mathrm{mg} \mathrm{kg}^{-1}$ led to an increase in GPx activity, compared with the remaining two doses, and the highest blood GPx activity was observed in the $\mathrm{Cu}-\mathrm{NP}_{2}$ group ( $\mathrm{P}<0.05$ vs. all other groups). The opposite trend was noted in FRAP values (cf. the interaction), which were lowest in the $\mathrm{Cu}-\mathrm{NP}_{2}$ group $\left(\mathrm{P}<0.05\right.$ vs. all other groups) and higher in groups $\mathrm{Cu}-\mathrm{SUL}_{20}, \mathrm{Cu}-\mathrm{NP}_{20}, \mathrm{Cu}-\mathrm{SUL}_{10}$, and $\mathrm{Cu}-\mathrm{NP}_{10}\left(\mathrm{P}<0.05\right.$ vs. $\mathrm{Cu}-\mathrm{SUL}_{2}$ and $\left.\mathrm{Cu}-\mathrm{NP}_{2}\right)$. Regardless of $\mathrm{Cu}$ form, the lowest inclusion level of $\mathrm{Cu}\left(2 \mathrm{mg} \mathrm{kg}^{-1}\right)$ contributed to an increase in blood SOD activity and MDA concentration $\left(\mathrm{P}<0.05\right.$ vs. 10 and $\left.20 \mathrm{mg} \mathrm{kg}^{-1}\right)$.

Table 4. Hepatic $\mathrm{Cu}$ concentration and redox status parameters* in the birds' liver

\begin{tabular}{|c|c|c|c|c|c|}
\hline & $\begin{array}{c}\mathrm{Cu} \\
\left(\mathrm{mg} \mathrm{kg}^{-1}\right)\end{array}$ & $\begin{array}{c}\text { SOD } \\
\left(\mathrm{U} \mathrm{g}^{-1}\right)\end{array}$ & $\begin{array}{c}\mathrm{CAT} \\
\left(\mathrm{U} \mathrm{g}^{-1}\right)\end{array}$ & $\begin{array}{r}\mathrm{GSH}+\mathrm{GSSG} \\
\left.(\mu \mathrm{mol} \mathrm{kg})^{-1}\right)\end{array}$ & $\begin{array}{c}\text { MDA } \\
\left(\mu \mathrm{mol} \mathrm{kg}{ }^{-1}\right)\end{array}$ \\
\hline \multicolumn{6}{|l|}{ Group } \\
\hline $\mathrm{Cu}-\mathrm{SUL}_{20}$ & $7.80 \mathrm{bc}$ & 10.7 & 50.4 & 0.91 & 2.99 \\
\hline $\mathrm{Cu}-\mathrm{NP}_{20}$ & $9.84 \mathrm{a}$ & 8.70 & 44.7 & 0.98 & 2.95 \\
\hline $\mathrm{Cu}-\mathrm{SUL}_{10}$ & $9.16 \mathrm{ab}$ & 8.09 & 74.8 & 1.04 & 2.20 \\
\hline $\mathrm{Cu}-\mathrm{NP}_{10}$ & $8.03 \mathrm{abc}$ & 6.83 & 68.1 & 1.02 & 2.75 \\
\hline $\mathrm{Cu}-\mathrm{SUL}_{2}$ & $6.20 \mathrm{~cd}$ & 8.31 & 69.7 & 1.16 & 2.96 \\
\hline $\mathrm{Cu}-\mathrm{NP}_{2}$ & $5.79 \mathrm{~d}$ & 7.77 & 76.1 & 1.04 & 2.77 \\
\hline SEM & 0.326 & 0.239 & 2.119 & 0.023 & 0.107 \\
\hline \multicolumn{6}{|l|}{$\mathrm{Cu}$ addition (A) } \\
\hline $20 \mathrm{mg} \mathrm{kg}^{-1}$ & 8.82 & $9.68 \mathrm{a}$ & $47.6 \mathrm{~b}$ & $0.94 \mathrm{~b}$ & 2.97 \\
\hline $10 \mathrm{mg} \mathrm{kg}^{-1}$ & 8.60 & $7.46 \mathrm{~b}$ & $71.5 \mathrm{a}$ & $1.03 \mathrm{ab}$ & 2.48 \\
\hline $2 \mathrm{mg} \mathrm{kg}^{-1}$ & 6.00 & $8.04 \mathrm{~b}$ & $72.9 \mathrm{a}$ & $1.10 \mathrm{a}$ & 2.87 \\
\hline$P$ values & 0.001 & 0.001 & 0.001 & 0.015 & 0.143 \\
\hline \multicolumn{6}{|l|}{$\mathrm{Cu}$ form $(\mathrm{F})$} \\
\hline $\mathrm{Cu}-\mathrm{SUL}$ & 7.72 & $9.03 \mathrm{a}$ & 65.0 & 1.03 & 2.72 \\
\hline $\mathrm{Cu}-\mathrm{NP}$ & 7.89 & $7.77 \mathrm{~b}$ & 63.0 & 1.01 & 2.82 \\
\hline $\mathrm{P}$ values & 0.753 & 0.001 & 0.427 & 0.622 & 0.616 \\
\hline $\mathrm{A} \times \mathrm{F}$ interaction & 0.045 & 0.273 & 0.071 & 0.200 & 0.321 \\
\hline
\end{tabular}

*SOD, superoxide dismutase; CAT, catalase; GSH+GSSG, total glutathione; MDA, malondialdehyde;

$\mathrm{a}, \mathrm{b}, \mathrm{c}, \mathrm{d}-$ mean values within a column with unlike letters were shown to be significantly different $(\mathrm{P}<0.05)$; differences among the groups $\mathrm{Cu}-\mathrm{SUL}_{20}, \mathrm{Cu}-\mathrm{SUL}_{10}, \mathrm{Cu}-\mathrm{SUL}_{220}, \mathrm{Cu}-\mathrm{NP}_{20}, \mathrm{Cu}-\mathrm{NP}_{10}$, and $\mathrm{Cu}-\mathrm{NP}_{2}$ were indicated with superscripts only in the case of a statistically significant interaction $\mathrm{A} \times \mathrm{F}(\mathrm{P}<0.05)$. 
The highest and the lowest $\mathrm{Cu}$ concentrations in the liver were noted in turkeys fed diets with 20 and $2 \mathrm{mg} \mathrm{kg}^{-1}$ of additional $\mathrm{Cu}$ in the form of nanoparticles, respectively (Table 4). Higher hepatic $\mathrm{Cu}$ accumulation was observed in response to dietary $\mathrm{Cu}$ supplementation in the form of nanoparticles at $20 \mathrm{mg} \mathrm{kg}^{-1}$ (cf. level $\times$ form interaction). Irrespective of $\mathrm{Cu}$ form, the $20 \mathrm{mg} \mathrm{kg}^{-1}$ treatment was associated with the lowest CAT activity and the highest SOD activity in the liver $(\mathrm{P}<0.05$ vs. 10 and $2 \mathrm{mg} \mathrm{kg}^{-1}$ treatments). Additionally, hepatic SOD activity was lower in turkeys fed diets containing $\mathrm{Cu}-\mathrm{NP}(\mathrm{P}<0.05$ vs. $\mathrm{Cu}-\mathrm{SUL}$ treatments $)$. The highest concentration of total glutathione (GSH+GSSG) in the liver was noted upon dietary $\mathrm{Cu}$ supplementation at $2 \mathrm{mg} \mathrm{kg}^{-1}\left(\mathrm{P}<0.05 \mathrm{vs}\right.$. the $20 \mathrm{mg} \mathrm{kg}^{-1}$ treatment $)$.

Table 5. $\mathrm{Cu}$ concentration and redox status parameters* in the breast meat of turkeys

\begin{tabular}{|c|c|c|c|c|c|}
\hline & $\begin{array}{c}\mathrm{Cu} \\
\left(\mathrm{mg} \mathrm{kg}^{-1}\right)\end{array}$ & $\begin{array}{l}\text { SOD } \\
\left(\mathrm{U} \mathrm{g}^{-1}\right)\end{array}$ & $\begin{array}{c}\mathrm{CAT} \\
\left(\mathrm{U} \mathrm{g}^{-1}\right)\end{array}$ & $\begin{array}{r}\mathrm{GSH}+\mathrm{GSSG} \\
\left.(\mu \mathrm{mol} \mathrm{kg})^{-1}\right)\end{array}$ & $\begin{array}{c}\text { MDA } \\
(\mu \mathrm{mol} \mathrm{kg})\end{array}$ \\
\hline \multicolumn{6}{|l|}{ Group } \\
\hline $\mathrm{Cu}-\mathrm{SUL}_{20}$ & 4.25 & 2.74 & 3.48 & 1.00 & $2.63 \mathrm{a}$ \\
\hline $\mathrm{Cu}-\mathrm{NP}_{20}$ & 4.41 & 3.70 & 4.11 & 0.96 & $1.92 \mathrm{~b}$ \\
\hline $\mathrm{Cu}-\mathrm{SUL}_{10}$ & 3.43 & 3.28 & 3.99 & 1.09 & $1.87 \mathrm{~b}$ \\
\hline $\mathrm{Cu}-\mathrm{NP}_{10}$ & 2.94 & 3.56 & 5.82 & 1.02 & $1.86 \mathrm{~b}$ \\
\hline $\mathrm{Cu}-\mathrm{SUL}_{2}$ & 2.65 & 3.27 & 4.21 & 1.15 & 2.01 \\
\hline $\mathrm{Cu}-\mathrm{NP}_{2}$ & 2.48 & 3.55 & 5.30 & 1.10 & $2.62 \mathrm{a}$ \\
\hline SEM & 0.198 & 0.118 & 0.170 & 0.014 & 0.071 \\
\hline \multicolumn{6}{|l|}{$\mathrm{Cu}$ addition $(\mathrm{A})$} \\
\hline $20 \mathrm{mg} \mathrm{kg}^{-1}$ & $4.33 \mathrm{a}$ & 3.22 & $3.80 \mathrm{~b}$ & $0.98 \mathrm{c}$ & 2.28 \\
\hline $10 \mathrm{mg} \mathrm{kg}^{-1}$ & $3.18 \mathrm{~b}$ & 3.42 & $4.91 \mathrm{a}$ & $1.06 \mathrm{~b}$ & 1.86 \\
\hline $2 \mathrm{mg} \mathrm{kg}^{-1}$ & $2.57 \mathrm{~b}$ & 3.41 & $4.75 \mathrm{a}$ & $1.13 \mathrm{a}$ & 2.32 \\
\hline $\mathrm{P}$ values & 0.001 & 0.732 & 0.002 & $<0.001$ & 0.002 \\
\hline \multicolumn{6}{|l|}{$\mathrm{Cu}$ form $(\mathrm{F})$} \\
\hline Cu-SUL & 3.44 & $3.10 \mathrm{~b}$ & $4.21 \mathrm{~b}$ & $1.08 \mathrm{a}$ & 2.17 \\
\hline $\mathrm{Cu}-\mathrm{NP}$ & 3.28 & $3.61 \mathrm{a}$ & $5.30 \mathrm{a}$ & $1.03 \mathrm{~b}$ & 2.13 \\
\hline $\mathrm{P}$ values & 0.638 & 0.033 & 0.001 & 0.025 & 0.722 \\
\hline $\mathrm{A} \times \mathrm{F}$ interaction & 0.751 & 0.391 & 0.177 & 0.802 & 0.001 \\
\hline
\end{tabular}

*SOD, superoxide dismutase; CAT, catalase; GSH+GSSG, total glutathione; MDA, malondialdehyde;

$\mathrm{a}, \mathrm{b}$ - mean values within a column with unlike letters were shown to be significantly different $(\mathrm{P}<0.05)$; differences among the groups $\mathrm{Cu}-\mathrm{SUL}_{20}, \mathrm{Cu}-\mathrm{SUL}_{10}, \mathrm{Cu}-\mathrm{SUL}_{220}, \mathrm{Cu}-\mathrm{NP}_{20}, \mathrm{Cu}-\mathrm{NP}_{10}$, and $\mathrm{Cu}-\mathrm{NP}_{2}$ were indicated with superscripts only in the case of a statistically significant interaction $\mathrm{A} \times \mathrm{F}(\mathrm{P}<0.05)$.

Two-way ANOVA revealed that regardless of $\mathrm{Cu}$ form, the highest $\mathrm{Cu}$ supplementation level caused a decrease in CAT activity and total glutathione concentrations in the breast muscles of turkeys ( $\mathrm{P}<0.05$ vs. the other treatments) (Table 5). The highest GSH+GSSG concentrations in breast muscles were noted in the $2 \mathrm{mg} \mathrm{kg}^{-1}$ treatment $\left(\mathrm{P}<0.05\right.$ vs. 10 and $20 \mathrm{mg} \mathrm{kg}^{-1}$ treatments $)$. An analysis of dietary 
$\mathrm{Cu}$ forms indicated that $\mathrm{Cu}-\mathrm{NP}$ increased CAT and SOD activities, and decreased total glutathione concentrations in breast muscles, as compared with $\mathrm{Cu}-\mathrm{SUL}$. Surprisingly, the level $\times$ form interaction revealed the highest MDA concentrations in breast muscles in groups $\mathrm{Cu}-\mathrm{SUL}_{20}$ and $\mathrm{Cu}-\mathrm{NP}_{2}(\mathrm{P}<0.05$ vs. all other groups $)$.

Table 6. Levels of lysozyme, ceruloplasmin (Cp), immunoglobulins (IgA, IgY and IgM), and interleukine-6 (IL-6) in the blood plasma of turkeys

\begin{tabular}{|c|c|c|c|c|c|c|}
\hline & $\begin{array}{l}\text { Lysozyme } \\
\left(\mu \mathrm{g} \mathrm{mL}^{-1}\right)\end{array}$ & $\begin{array}{c}\mathrm{Cp} \\
\left(\mathrm{mg} \mathrm{L}^{-1}\right)\end{array}$ & $\begin{array}{c}\operatorname{IgY} \\
\left(\mathrm{ng} \mathrm{mL} \mathrm{mL}^{-1}\right)\end{array}$ & $\begin{array}{c}\operatorname{IgM} \\
\left(\mathrm{ng} \mathrm{mL}^{-1}\right)\end{array}$ & $\begin{array}{c}\operatorname{IgA} \\
\left.\text { (ng } \mathrm{nmL}^{-1}\right)\end{array}$ & $\begin{array}{c}\mathrm{IL}-6 \\
\left(\mathrm{pg} \mathrm{mL}^{-1}\right)\end{array}$ \\
\hline \multicolumn{7}{|l|}{ Group } \\
\hline $\mathrm{Cu}-\mathrm{SUL}_{20}$ & 2.77 & 0.80 & 797 & 339 & 24.5 & $6.06 \mathrm{~b}$ \\
\hline $\mathrm{Cu}-\mathrm{NP}_{20}$ & 2.05 & 0.88 & 893 & 330 & 22.8 & $8.62 \mathrm{a}$ \\
\hline $\mathrm{Cu}-\mathrm{SUL}_{10}$ & 2.85 & 1.13 & 753 & 369 & 20.6 & $5.21 \mathrm{~b}$ \\
\hline $\mathrm{Cu}-\mathrm{NP}_{10}$ & 2.31 & 0.76 & 877 & 288 & 20.7 & $3.21 \mathrm{c}$ \\
\hline $\mathrm{Cu}-\mathrm{SUL}_{2}$ & 2.64 & 0.57 & 741 & 390 & 29.0 & $3.80 \mathrm{c}$ \\
\hline $\mathrm{Cu}-\mathrm{NP}_{2}$ & 2.41 & 0.69 & 723 & 357 & 25.6 & $5.71 \mathrm{~b}$ \\
\hline SEM & 0.093 & 0.050 & 15.36 & 11.331 & 0.860 & 0.296 \\
\hline \multicolumn{7}{|l|}{$\mathrm{Cu}$ addition (A) } \\
\hline $20 \mathrm{mg} \mathrm{kg}^{-1}$ & 2.41 & $0.84 \mathrm{a}$ & $845 \mathrm{a}$ & 334 & $23.6 \mathrm{ab}$ & 7.34 \\
\hline $10 \mathrm{mg} \mathrm{kg}^{-1}$ & 2.58 & $0.94 \mathrm{a}$ & $815 \mathrm{a}$ & 328 & $20.6 \mathrm{~b}$ & 4.21 \\
\hline $2 \mathrm{mg} \mathrm{kg}^{-1}$ & 2.52 & $0.63 \mathrm{~b}$ & $732 \mathrm{~b}$ & 373 & $27.3 \mathrm{a}$ & 4.76 \\
\hline$P$ values & 0.738 & 0.025 & 0.002 & 0.200 & 0.005 & $<0.001$ \\
\hline \multicolumn{7}{|l|}{$\mathrm{Cu}$ form $(\mathrm{F})$} \\
\hline $\mathrm{Cu}-\mathrm{SUL}$ & $2.75 \mathrm{a}$ & 0.83 & $763 b$ & 366 & 27.7 & 5.02 \\
\hline $\mathrm{Cu}-\mathrm{NP}$ & $2.26 \mathrm{~b}$ & 0.78 & $831 \mathrm{a}$ & 325 & 23.0 & 5.85 \\
\hline$P$ values & 0.008 & 0.532 & 0.011 & 0.067 & 0.285 & 0.013 \\
\hline $\mathrm{A} \times \mathrm{F}$ interaction & 0.524 & 0.066 & 0.063 & 0.401 & 0.655 & $<0.001$ \\
\hline
\end{tabular}

a, b, c - mean values within a column with unlike letters were shown to be significantly different $(\mathrm{P}<0.05)$; differences among the groups $\mathrm{Cu}-\mathrm{SUL}_{20}, \mathrm{Cu}-\mathrm{SUL}_{10}, \mathrm{Cu}-\mathrm{SUL}_{220}, \mathrm{Cu}-\mathrm{NP}_{20}, \mathrm{Cu}-\mathrm{NP}_{10}$, and $\mathrm{Cu}-\mathrm{NP}_{2}$ were indicated with superscripts only in the case of a statistically significant interaction $\mathrm{A} \times \mathrm{F}(\mathrm{P}<0.05)$.

Irrespective of $\mathrm{Cu}$ form, the $2 \mathrm{mg} \mathrm{kg}^{-1}$ treatment caused a significant decrease in $\mathrm{Cp}$ and $\mathrm{IgY}$ concentrations in the blood plasma of turkeys in comparison with the remaining two $\mathrm{Cu}$ doses (Table 6). In all treatments, nutritional levels of IgM were similar, however the $2 \mathrm{mg} \mathrm{kg}^{-1}$ treatment contributed to a significant increase in plasma IgA concentrations vs. the $\mathrm{Cu}$ dose of $10 \mathrm{mg} \mathrm{kg}^{-1}(\mathrm{P}<0.05)$. Dietary supplementation with $\mathrm{Cu}-\mathrm{NP}$ increased IgY concentrations and decreased lysozyme concentrations in the blood plasma of turkeys in comparison with the $\mathrm{Cu}-\mathrm{SUL}$ treatment. As demonstrated by the addition $\times$ form interaction, turkeys from the $\mathrm{Cu}-\mathrm{NP}_{20}$ group had elevated plasma IL-6 concentrations as compared with all other groups. 


\section{Discussion}

As summarized in a recent review article (Hill and Li, 2017), many reports have shown that nanoparticles may be effective animal growth promoters. But, a faster growth rate of broiler chickens was also reported in response to very high (100-450 $\mathrm{mg} \mathrm{kg}^{-1}$ ) dietary levels of conventional source of Cu (Samanta et al., 2011). At moderate addition of $\mathrm{Cu}$ to turkey diets, i.e. 15 and $65 \mathrm{mg} \mathrm{kg}^{-1}$, no differences in the growth performance parameters of birds were noted (Makarski et al., 2014). In the present study, supplemental $\mathrm{Cu}$ doses of 2, 10 and $20 \mathrm{mg} \mathrm{kg}^{-1}$ increased the total dietary $\mathrm{Cu}$ content to approximately 14,21 and $30 \mathrm{mg} \mathrm{kg}^{-1}$, respectively. It should be stressed that the above values obtained in the present experimental schema were below, similar to and higher than the inclusion rate of $25 \mathrm{mg} \mathrm{kg}^{-1}$ recommended for poultry diets in the EU (EFSA, 2016). But, neither the differences in dietary $\mathrm{Cu}$ supplementation levels nor the total $\mathrm{Cu}$ content of feed affected the final body weights of turkeys.

In the present study, blood plasma $\mathrm{Cu}$ concentration increased in response to the highest dietary addition of $\mathrm{Cu}-\mathrm{NP}$, relative to the identical amount of $\mathrm{Cu}-\mathrm{SUL}$. It can be assumed that such nanoparticles treatment led to enhanced $\mathrm{Cu}$ absorption in the gastrointestinal tract. Many in vitro experiments demonstrated that nanoparticles with reduced size and greater area exhibit a high rate of absorption in the stomach and intestines (Hussain et al., 2001; Tomaszewska et al., 2017).

Intensified oxidation processes in poultry tissues, manifested by a decrease in SOD and CAT activity, were noted in studies investigating the effect of high dietary $\mathrm{Cu}$ doses, above $250 \mathrm{mg} \mathrm{kg}^{-1}$ (Ajuwon et al., 2011). It is well known that superoxide dismutase is involved in the first line of antioxidant defence against toxic reactive oxygen species (McCord, 1983), and diminished activities of antioxidant enzymes could negatively affect cellular resistance against the oxidant-induced damage of cell genome (Amstad et al., 1994). In an earlier experiment, a decrease in dietary $\mathrm{Cu}$ content from 30 to approximately $11 \mathrm{mg} \mathrm{kg}^{-1}$ did not influence SOD activity in the blood of turkeys (Mikulski et al., 2009). In the current study, a decrease in dietary $\mathrm{Cu}$ content from 20 and 10 to $2 \mathrm{mg} \mathrm{kg}^{-1}$ increased SOD and GPx activities in birds' blood. No differences were found in the levels of important antioxidant, namely plasma glutathione. However, irrespective of the $\mathrm{Cu}$ source elevated plasma MDA levels followed dietary treatment with $2 \mathrm{mg}$ of $\mathrm{Cu} \mathrm{kg}^{-1}$. Low-grade $\mathrm{Cu}-\mathrm{NP}$ contributed to a decrease in FRAP values. Our results could suggest that the highest and medium $\mathrm{Cu}$ doses exerted antioxidant effects, relative to diets with the lowest $\mathrm{Cu}$ content. Such observations were also made by other authors who found that high cytoplasmic $\mathrm{Cu}$ concentrations may enhance GPx activity and more effectively protect cells against peroxide-induced damage (Freedman and Wolterbeek, 1989). The above findings indicate that in comparison with the addition of $2 \mathrm{mg} \mathrm{Cu} \mathrm{kg}{ }^{-1}$, dietary supplementation at 10 and $20 \mathrm{mg} \mathrm{kg}^{-1}$ did not exert pro-oxidant effects which were noted in response to higher pharmacological concentrations of dietary $\mathrm{Cu}$ (Ajuwon et al., 2011).

Previous studies have shown that hepatic $\mathrm{Cu}$ concentration is influenced by variations in dietary $\mathrm{Cu}$ levels (Bao et al., 2007). In the present experiment, reduced 
dietary $\mathrm{Cu}$ content (from $20-10$ to $2 \mathrm{mg} \mathrm{kg}^{-1}$ ) led to a decrease in $\mathrm{Cu}$ concentration and an increase in total glutathione levels in the liver. It has been reported that $\mathrm{Cu}$ reduces the concentration of hepatic glutathione through the stimulation of 3-hydroxyl-3-methylglutaryl coenzyme reductase (Kim et al., 1992). In our experiment, despite the noted decrease in glutathione levels, MDA concentration did not increase in the liver. An increase in MDA concentration, indicative of intensified oxidation processes in the liver, was observed in broiler chickens fed diets supplemented with $250 \mathrm{mg} \mathrm{Cu}$ per one $\mathrm{kg}$ (Ajuwon et al., 2011). In another experiment, a low dose of supplemental $\mathrm{Cu}\left(50 \mathrm{mg} \mathrm{kg}^{-1}\right)$ only numerically decreased MDA concentration in the liver. In our study, an increase in dietary $\mathrm{Cu}$ content from 2 to $10 \mathrm{mg} \mathrm{kg}^{-1}$ had no effect on the analysed indicators of the liver redox status. The highest dose of supplemental $\mathrm{Cu}$ did not increase MDA concentration, but it increased SOD activity, decreased CAT activity and further reduced GSH+GSSG and vitamin C levels with a simultaneous decrease in MDA concentration in the liver. Our findings could suggest that dietary supplementation with $20 \mathrm{mg} \mathrm{Cu}$ per kg exerted both antioxidant and pro-oxidant effects in turkeys. The replacement of $\mathrm{Cu}-\mathrm{SUL}$ with $\mathrm{Cu}-\mathrm{NP}$ resulted in decreased CAT activity but it did not affect other indicators of the liver redox status.

Other authors (Xiang et al., 2009) found no differences in MDA concentration in the muscles of broiler chickens fed diets without and with different inclusion levels of $\mathrm{Cu}$, from 50 to $350 \mathrm{mg} \mathrm{kg}^{-1}$. In the present experiment, a decrease in MDA concentration was noted if $\mathrm{Cu}$ addition was reduced from 20 to $10 \mathrm{mg} \mathrm{kg}^{-1}$ or if $\mathrm{Cu}-\mathrm{SUL}$ was replaced with $\mathrm{Cu}-\mathrm{NP}$. However, the lowest dose of $\mathrm{Cu}-\mathrm{NP}$ increased MDA levels in breast meat. A decrease in dietary $\mathrm{Cu}$ addition from 20 to $10 \mathrm{mg} \mathrm{kg}^{-1}$ lowered $\mathrm{Cu}$ levels and increased CAT activity and total glutathione concentrations in breast muscles. The lowest $\mathrm{Cu}$ addition admittedly increased total glutathione levels, however, it did not improve other indicators of the antioxidant status of breast meat, compared with the medium dose of $\mathrm{Cu}$. The replacement of $\mathrm{Cu}-\mathrm{SUL}$ with $\mathrm{Cu}-\mathrm{NP}$ resulted in similar concentrations of $\mathrm{Cu}$, an increase in SOD and CAT activities, and a decrease in total glutathione levels in meat.

In brief, the antioxidant and immune status of the blood, liver and breast muscles in turkeys indicates that $10 \mathrm{mg} \mathrm{kg}^{-1}$ is the optimal inclusion level of additional dietary $\mathrm{Cu}$. Both two-fold higher and five-fold lower $\mathrm{Cu}$ addition negatively influenced selected parameters of the antioxidant and immune status of birds. The replacement of $\mathrm{Cu}-\mathrm{SUL}$ with $\mathrm{Cu}-\mathrm{NP}$ induced both desirable and undesirable changes in selected parameters of the analysed tissues, but the dose of $10 \mathrm{mg} \mathrm{kg}^{-1}$ should be considered as safest and most effective. Nevertheless, the efficacy of metal nanoparticles in turkey nutrition requires further research, and this issue will be addressed in our future studies.

Trace elements, including $\mathrm{Cu}$, have a considerable effect on the immune system (Percival, 1998), and a $\mathrm{Cu}$ deficit may lead to a decrease in Cp levels (Wang et al., 2011). In the present experiment, $\mathrm{Cp}$ concentration decreased in response to an increase in dietary $\mathrm{Cu}$ content from 20 and 10 to $2 \mathrm{mg} \mathrm{kg}^{-1}$. At the same time, the level of the most important immunoglobulin, Y, decreased. This is consistent with the results of another experiment (Wang et al., 2011) where the blood levels of IgM, 
IgG and IgA depended on the addition of $\mathrm{Cu}$ to broiler chicken diets. In our experiment, decreased $\mathrm{Cp}$ levels were noted in turkeys fed diets with the lowest $\mathrm{Cu}$ doses, whereas IL-6 levels increased in birds fed diets supplemented with $20 \mathrm{mg} \mathrm{Cu} \mathrm{kg}^{-1}$, in comparison with the remaining treatments. It has been suggested that serum $\mathrm{Cp}$ levels increase as part of the stress response of hepatocytes and the release of inflammatory mediators (Malavolta et al., 2015), and that interleukin-6 is the key cytokine responsible for the activation of $\mathrm{B}$ cells and stimulation of the synthesis of acute phase proteins, including Cp (Dinant and Dijkmans, 1999).

\section{Conclusions}

In conclusion, the turkeys' redox and immune status of blood, liver and breast muscles, characterized in this study, indicates that $10 \mathrm{mg} \mathrm{kg}^{-1}$ is the optimal dietary inclusion level of additional $\mathrm{Cu}$. Both two-fold higher and five-fold lower $\mathrm{Cu}$ addition to a diet had a negative influence on selected antioxidant and immune parameters of birds. The results also indicate that the replacement of $\mathrm{Cu}-\mathrm{SUL}$ with $\mathrm{Cu}-\mathrm{NP}$ induced both desirable and undesirable changes in selected parameters of blood (increase in IgY and IL-6 levels), liver (decreased SOD activity) and breast muscles (increased CAT and SOD activities, decreased GSH+GSSG levels). Lower addition levels of $\mathrm{Cu}-\mathrm{NP}$ ( 2 and $10 \mathrm{mg} \mathrm{kg}^{-1}$ ) exerted similar physiological effects to $\mathrm{Cu}-\mathrm{SUL}$, whereas $20 \mathrm{mg} \mathrm{kg}^{-1}$ of Cu-NP negatively affected the redox status and stimulated the synthesis of the proinflammatory cytokine IL-6. It can be concluded that the efficacy of $\mathrm{Cu}$ nanoparticles in turkey nutrition remains debatable. Further research, including an economic analysis, is needed to investigate the advantages and disadvantages of this feed additive.

\section{References}

A juw on O.R., I d ow u O.M.O., A fol a bi S.A., Ke hinde B.O., Og un tola O.O., Olatun b o s u n K.O. (2011). The effects of dietary copper supplementation on oxidative and antioxidant systems in broiler chickens. Arch. Zootec., 60: 275-282.

A 1 b a n e s e A., Tang P.S., Ch a n W.C.W. (2012). The effect of nanoparticle size, shape, and surface chemistry on biological systems. Annu. Rev. Biomed. Eng., 14: 1-16.

A mstad P., Moret R., Cerutti P. (1994). Glutathione peroxidase compensates for the hypersensitivity of $\mathrm{Cu}, \mathrm{Zn}$-superoxide dismutase overproducers to oxidant stress. J. Biol. Chem., 269: 1606-1609.

B a o Y.M., Ch o c t M., Ij i P., B rue rt on A. (2007). Effect of organically complexed copper, iron, manganese and zinc on broiler performance, mineral excretion and accumulation in tissues. J. Appl. Poultry Res., 16: 448-455.

B ung lavan S.J., D a s s A.K.G., Shriva s t a va S. (2014). Use of nanoparticles as feed additives to improve digestion and absorption in livestock. Livestock Res. Int., 2: 36-47.

D in an t H.J., D i j kmans B.A.C. (1999). New therapeutic targets for rheumatoid arthritis. Pharm. World Sci., 21: 49-59.

EFSA, Panel on Additives and Products or Substances used in Animal Feed (FEEDAP). (2016). Revision of the currently authorised maximum copper content in complete feed. EFSA J., 14: 4563.

El Sabry M.I., Mc Millin K.W., Sabliov C.M. (2018). Nanotechnology considerations for poultry and livestock production systems - a review. Ann. Anim. Sci., 18: 319-334. 
Freedman J.H., Wolterbeek H.T. (1989). The role of glutathione in copper metabolism and toxicity. J. Biol. Chem., 264: 5590-5605.

Hill E.K., Li J. (2017). Current and future prospects for nanotechnology in animal production. J. Anim. Sci. Biotechnol., 8: 26.

Hus s a in N., J a it ley V., Flor en ce A.T. (2001). Recent advances in the understanding of uptake of microparticles across the gastrointestinal lymphatics. Adv. Drug Deliv. Rev., 50: 107-142.

Hybrid Turkeys (2013). Nutrient Guidelines. http://resources.hybridturkeys.com/nutrition/commercialguidelines (accessed 09.07.2018).

K i m J.W., C h a o P.Y., A 11 en A. (1992). Inhibition of elevated hepatic glutathione abolishes copper deficiency cholesterolemia. FASEB J., 6: 2467-2471.

K l a s in g K.C. (1998). Nutritional modulation of resistance to infectious diseases. Poultry Sci., 77 : $1119-1125$.

Maheshwari S. (2013). Environmental impacts of poultry production. Poult. Fish Wildl. Sci., 1: 101-103.

Majewski M., Ognik K., Z duńczyk P., Juśkiewicz J. (2017). Effect of dietary copper nanoparticles versus one copper (II) salt: analysis of vasoreactivity in a rat model. Pharmacol. Rep., 69: $1282-1288$.

Makarski B., Gortat M., Lechowski J., Żukiewicz-Sobczak W., Sobczak P., $\mathrm{Z}$ a w iśla k K. (2014). Impact of copper $(\mathrm{Cu})$ at the dose of $50 \mathrm{mg}$ on haematological and biochemical blood parameters in turkeys, and level of $\mathrm{Cu}$ accumulation in the selected tissues as a source of information on product safety for consumers. Ann. Agric. Environ. Med., 21: 567-570.

Malavolta M., Piacenza F., Basso A., Giacconi R., Costarelli L., Mocchegia$\mathrm{n}$ i E. (2015). Serum copper to zinc ratio: relationship with aging and health status. Mech. Ageing. Dev., 151: 93-100.

M c C ord J.M. (1983). The superoxide free radical: its biochemistry and pathophysiology. Surgery, 94: 412-414.

Mikulski D., Jankowski J., Zduńczyk Z., Wróblewska M., Mikulska M. (2009). Copper balance, bone mineralization and the growth performance of turkeys fed diet with two types of Cu supplements. J. Anim. Feed Sci., 18: 677-688.

Nollet L., Huyghebaert G., Spring P. (2008). Effect of different levels of dietary organic (Biolpex) trace minerals on live performance of broiler chickens by growth phases. J. Appl. Poultry Res., 17: 109-115.

NRC (1994). Nutrient Requirements of Poultry. 9th rev. ed. Natl. Acad. Press, Washington, DC.

O g n i k K., We r t e l e c k i T. (2012). Effect of different vitamin E sources and levels on selected oxidative status indices in blood and tissues as well as on rearing performance of slaughter turkey hens. J. Appl. Poultry Res., 2: 259-271.

Ognik K., Stępniowska A., Cholewińska E., Kozłowski K. (2016). The effect of administration of copper nanoparticles to chickens in drinking water on estimated intestinal absorption of iron, zinc, and calcium. Poultry Sci., 95: 2045-2051.

Per c iv a 1 S.S. (1998). Copper and immunity. Am. J. Clin. Nutr., 67: 1064S-1068S.

S a m a n t a B., Gh o sh P.R., B is w as A., D a s S.K. (2011). The effects of copper supplementation on the performance and hematological parameters of broiler chickens. Asian-Australas. J. Anim. Sci., 24: 1001-1006.

Smulikowska S., Rutkowski A. (2005). Recommended Allowances and Nutritive Value of Feedstuffs - Poultry Feeding Standards (in Polish). 5th ed. Smulikowska, S., Rutkowski, A., Eds. The Kielanowski Institute of Animal Physiology and Nutrition, Jablonna, PAS, Poland.

S underman Jr F.W., N o moto S. (1970). Measurement of human serum ceruloplasmin by its p-phenylenediamine oxidase activity. Clin. Chem., 16: 903-910.

Tomaszewska E., Muszyński S., Ognik K., Dobrowolski P., Kwiecień M., Juśkiewicz J., Chocyk D., Świetlicki M., Blicharski T., Gładyszewska B. (2017). Comparison of the effect of dietary copper nanoparticles with copper (II) salt on bone geometric and structural parameters as well as material characteristics in a rat model. J. Trace Elem. Med. Biol., 42: 103-110.

Wang C., Wang M.Q., Ye S.S., Ta o W.J., D u Y.J. (2011). Effects of copper-loaded chitosan nanoparticles on growth and immunity in broilers. Poultry Sci., 90: 2223-2228. 
X i a n g - Q i Z., Z h a n g K.-Y., D ing X.-M., B a i S.-P. (2009). Effects of dietary supplementation with copper sulfate or tribasic copper chloride on carcass characteristics, tissular nutrients deposition and oxidation in broilers. Pakistan J. Nutr., 8: 1114-1119.

Received: 9 VII 2018

Accepted: 20 XI 2018 